\title{
PENGARUH AUDIT INTERNAL TERHADAP KUALITAS PELAPORAN KEUANGAN
}

\author{
Oleh: \\ Ade Suherman \& Yuyun Susanti \\ Dosen Program Studi Pendidikan Akuntansi FKIP Universitas Galuh \\ Jl. R.E. Martadinata No. 150, Ciamis 46274 Jawa Barat \\ Email: adesuhermana@gmail.com
}

\begin{abstract}
ABSTRAK
Tujuan dari penelitian ini adalah untuk mengetahui pelaksanaan audit internal di RSUD Kota Banjar, untuk mengetahui kualitas pelaporan keuangan di RSUD Kota Banjar, dan untuk mengetahui pengaruh audit internal terhadap kualitas pelaporan keuangan di RSUD Kota Banjar. Penelitian ini didasarkan adanya informasi bahwa hasil audit yang dilakukan oleh inspektorat kota banjar terhadap pelaporan keuangan RSUD Kota Banjar mendapatkan opini Wajar Dengan Pengecualian (WDP). Hal tersebut menunjukan bahwa pelaksanaan audit internal dan kualitas pelaporan keuangan di RSUD Kota Banjar belum maksimal. Penelitian ini menggunakan metode penelitian deskriptif, sedangkan popoulasi dalam penelitian ini adalah Satuan Pengawas Internal (SPI) dan Bagian Keuangan, yang meliputi Kepala Bagian Keuangan beserta sub-subnya, yang berjumlah sebanyak 16 orang. Karena jumlah populasi kurang dari 100, maka seluruh populasi dijadikan sampel penelitian. Metode analisis data yang dipakai dalam penelitian ini adalah metode analisa kuantitatif, di mana untuk mencapai tujuan penelitian yaitu menganalisis pengaruh audit internal terhadap kualitas pelaporan keuangan adalah dengan menggunakan analisis regresi sederhana. Hasil penelitian menunjukan bahwa pelaksanaan audit internal dan kualitas pelaporan keuangan di RSUD Kota Banjar sudah sangat baik. Sejalan dengan hipotesis dan penelitian terdahulu, hasil pengujian di RSUD Kota Banjar menunjukan bahwa terdapat pengaruh yang signifikan audit internal terhadap kualitas pelaporan keuangan.
\end{abstract}

Kata Kunci: Audit internal, kualitas pelaporan keuangan

\section{PENDAHULUAN}

Informasi yang disajikan pada pelaporan keuangan merupakan tanggung jawab manajemen. Manajemen harus menyajikan informasi dengan jujur dan sesuai dengan keadaan yang ada. Namun, pada beberapa entitas internasional pelaporan keuangan tidak hanya dibuat oleh manajemen. Peran fungsi audit internal menjadi lebih diperluas untuk meningkatkan kualitas pelaporan keuangan yang awalnya hanya tanggung jawab manajemen.

Salah satu inti dari tujuan audit internal adalah mengatur secara sistematis serta mengevaluasi pengendalian intern dalam perusahaan. Namun pada kenyataannya pengendalian intern sering tidak berjalan sesuai dengan konsepnya, dikarenakan kurangnya tanggungjawab dalam perusahaan dan banyaknya penyimpangan-penyimpangan dalam perusahaan.

Penelitian ini berusaha mengembangkan dari penelitian yang sudah ada dan membuktikan pengaruh antara fungsi audit internal dengan kualitas pelaporan keuangan. Pada penilitian ini, fokusnya adalah meneliti pengaruh audit internal terhadap kualitas pelaporan keuangan pada
Rumah Sakit Umum Daerah (RSUD) Kota Banjar.

Menurut Bastian (2010: 6) bahwa Rumah Sakit merupakan salah satu organisasi sektor publik, dimana organisasi sektor publik adalah organisasi yang menghimpun dana dari masyarakat dengan tujuan untuk mensejahterakan masyarakat/publik. RSUD Kota Banjar pun merupakan organisasi sektor publik yang menghimpun dana dari masyarakat dengan tujuan untuk mensejahterkan masyarakat dalam bentuk memberikan pelayanan yang memadai dibidang kesehatan.

Sebagai lembaga penghimpun dana dari masyarakat, kualitas keuangan RSUD Kota Banjar merupakan hal penting sebagai salah satu indikator akan penilaian kinerjanya. Kemampuan RSUD Kota Banjar dalam menjalankan kegiatan operasinya, yaitu memberikan pelayanan kesehatan yang memadai kepada masyarakat tercermin dari pelaporan keuangan. Sebagai badan yang mengelola berbagai sumber daya yang dimiliki, RSUD Kota Banjar juga memerlukan manajemen pengendalian internal yang baik sehingga dapat menjalankan kegiatannya secara 
continue, dengan memaksimalkan auditor internal yang dimiliki RSUD Kota Banjar agar pengelolaan keuangannya sesuai dengan prinsip good governance, yaitu transparan, partisipatif dan akuntabel.

Audit internal sebagai salah satu komponen pengendalian internal di RSUD Kota Banjar belum sepenuhnya menjalankan tugasnya dengan baik. Hal tersebut terbukti dari hasil audit yang dilakukan oleh Inspektorat Kota Banjar semenjak 3 tahun terakhir, RSUD Kota Banjar mendapatkan opini Wajar Dengan Pengecualian (WDP), dimana hal tersebut menunjukan bahwa kualitas pelaporan keuangan RSUD Kota Banjar belum sesuai dengan tujuan pelaporan keuangan, seperti yang dinyatakan oleh Amalia (2014:78) di atas.

Berdasarkan uraian latar belakang penelitian di atas, maka tujuan penelitian ini adalah untuk mengetahui: (1) pelaksanaan audit internal di RSUD Kota Banjar; (2) pelaksanaan kualitas pelaporan keuangan di RSUD Kota Banjar; dan (3) pengaruh audit internal terhadap kualitas pelaporan keuangan di RSUD Kota Banjar.

\section{METODE PENELITIAN}

Penelitian ini menggunakan metode penelitian deskriptif, sedangkan popoulasi dalam penelitian ini adalah Satuan Pengawas Internal (SPI) dan Bagian Keuangan, yang meliputi Kepala Bagian Keuangan beserta subsubnya, yang berjumlah sebanyak 16 orang. Karena jumlah populasi kurang dari 100, maka seluruh populasi dijadikan sampel penelitian.

Daftar yang menjadi populasi dalam penelitian disajikan dalam tabel 3.2 berikut ini:

Tabel 3.2

Daftar Populasi

\begin{tabular}{clc}
\hline No & \multicolumn{1}{c}{ Jabatan } & Jumlah \\
\hline 1 & $\begin{array}{l}\text { Kepala Satuan Pengawas } \\
\text { Internal (SPI) }\end{array}$ & 1 orang \\
\hline 2 & $\begin{array}{l}\text { Anggota Satuan Pengawas } \\
\text { Internal (SPI) }\end{array}$ & orang \\
\hline 3 & Kepala Bagian Keuangan & 1 orang \\
\hline 4 & $\begin{array}{l}\text { Kepala Sub Bagian } \\
\text { Penyusunan Anggaran }\end{array}$ & 1 orang \\
\hline 5 & $\begin{array}{l}\text { Anggota Bagian } \\
\text { Penyusunan Anggaran }\end{array}$ & 2 orang \\
\hline 6 & $\begin{array}{l}\text { Kepala Sub Bagian } \\
\text { Perbendaharaan }\end{array}$ & 1 orang \\
\hline
\end{tabular}

\begin{tabular}{|c|c|c|}
\hline 7 & $\begin{array}{l}\text { Anggota Bagian } \\
\text { Perbendaharaan }\end{array}$ & 2 orang \\
\hline 8 & $\begin{array}{l}\text { Kepala Sub Bagian } \\
\text { Akuntansi dan Mobilisasi } \\
\text { Dana }\end{array}$ & 1 orang \\
\hline 9 & $\begin{array}{l}\text { Anggota Bagian Akuntansi } \\
\text { dan Mobilisasi Dana }\end{array}$ & 4 orang \\
\hline & Jumlah & 16 orang \\
\hline
\end{tabular}

Metode analisis data yang dipakai dalam penelitian ini adalah metode analisa kuantitatif, di mana untuk mencapai tujuan penelitian yaitu menganalisis pengaruh audit internal terhadap kualitas pelaporan keuangan adalah dengan menggunakan analisis regresi sederhana.

Model penelitian dalam menguji varibelvariabel tersebut dapat disusun dalam fungsi atau persamaan sebagai berikut:

$$
\hat{\mathrm{Y}}=a+b X
$$

\section{HASIL PENELITIAN DAN PEMBAHASAN}

Skor yang dihasilkan atas tanggapan responden terhadap pernyataan-pernyataan pelaksanaan audit internal di RSUD Kota Banjar adalah sebesar 1.297. Berdasarkan tabel klasifikasi interval audit internal, menunjukan bahwa penilaian terhadap capaian skor tersebut adalah sangat baik. Hal tersebut menjelaskan bahwa audit internal di RSUD Kota Banjar telah dilaksanakan dengan sangat baik.

Hasil tanggapan responden terhadap pernyataan-pernyataan pelaksanaan audit internal di RSUD Kota Banjar bertolak belakang dengan keadaan yang sebenarnya. Hal tersebut dibuktikan dengan hasil audit yang dilakukan oleh pihak inspektorat, dimana pelaporan keuangan RSUD Kota Banjar mendapatkan opini Wajar Dengan Pengecualian (WDP). Hasil capaian opini Wajar Dengan Pengecualian (WDP) tersebut menunjukan bahwa pelaksanaan audit internal yang dilakukan oleh Satuan Pengawas Internal (SPI) belum maksimal. Oleh karena itu perlu adanya optimalisasi terhadap pelaksanaan audit internal yang dilakukan oleh Satuan Pengawas Internal (SPI) RSUD Kota Banjar.

Skor yang dihasilkan atas tanggapan responden terhadap pernyataan-pernyataan pelaksanaan kualitas pelaporan keuangan di RSUD Kota Banjar adalah sebesar 709. Berdasarkan tabel klasifikasi interval kualitas pelaporan keuangan, menunjukan bahwa 
penilaian terhadap capaian skor tersebut adalah sangat baik. Hal tersebut menjelaskan bahwa kualitas pelaporan keuangan di RSUD Kota Banjar telah dilaksanakan dengan sangat baik.

Hasil tanggapan responden terhadap pernyataan-pernyataan mengenai kualitas pelaporan keuangan RSUD Kota Banjar bertolak belakang dengan keadaan yang sebenarnya. Hal tersebut dibuktikan dengan hasil audit yang dilakukan oleh pihak inspektorat, dimana pelaporan keuangan RSUD Kota Banjar mendapatkan opini Wajar Dengan Pengecualian (WDP). Hasil capaian opini Wajar Dengan Pengecualian (WDP) tersebut menunjukan bahwa kualitas pelaporan keuangan RSUD Kota Banjar belum maksimal.

Berdasarkan analisis statistik dalam penelitian ini dihasilkan nilai signifikansi yaitu 0,44, dimana nilai tersebut lebih besar dibandingkan dengan tingkat signifikansi 0,05 $(0,44>0,05)$, artinya variabel dependen kualitas pelaporan keuangan $(\mathrm{Y})$ dapat dijelaskan oleh variabel independen audit internal (X). Nilai $\mathrm{t}_{\text {hitung }}$ untuk audit internal adalah 3,344. Dengan demikian dapat diketahui bahwa $t_{\text {hitung }}>$ dari $\mathrm{t}_{\text {tabel }}$ yaitu 3,344 > 2,144, maka Hipotesis $\left(\mathrm{H}_{\mathrm{a}}\right)$ pada penelitian ini diterima, artinya ada pengaruh yang positif dan signifikan pelaksanaan audit internal terhadap kualitas pelaporan keuangan.

Penelitian ini sejalan dengan penilitian yang dilakukan oleh Daniel Susanto (2003), dimana hasil penelitiannya menjelaskan bahwa audit internal berperan terhadap kepatuhan manajemen, terutama dalam rangka pengendalian intern perusahaan, dimana salah satu tujuan dilakukannya proses pengendalian intern adalah agar dapat dipercayainya laporan keuangan. Penelitian lain yang dilakukan oleh Aristanti Widyaningsih (2010) didapat hasil bahwa audit internal berpengaruh terhadap efektivitas pengendalian intern biaya produksi. Sedangkan penelitian terdahulu lainnya yang sejalan dengan penelitian ini dilakukan oleh Lilir Sundayani (2013), di mana penelitian yang dilakukan didapat hasil bahwa audit internal berpengaruh terhadap penerapan GCG, dimana salah satu komponen GCG adalah pengendalian intern perusahaan yang berhubungan dengan kualitas laporan keuangan, sehingga laporan keuangan yang disajikan dapat dipercaya kebenarannya.

Dari ketiga penelitian terdahulu di atas, dapat diambil kesimpulan bahwa pelaksanaan audit internal berpengaruh terhadap variabel- variabel ataupun hal-hal yang ada kaitannya dengan kualitas pelaporan keuangan.

\section{PENUTUP Simpulan}

Berdasarkan hasil penelitian, simpulan dari pengaruh yang diberikan oleh variabel independen (audit internal) terhadap variabel dependen (kualitas pelaporan keuangan) adalah sebagai berikut: (1) Audit internal di Rumah Sakit Umum Daerah (RSUD) Kota Banjar mendapatkan penilaian yang sangat baik dari responden, artinya audit internal di RSUD Kota Banjar telah dilaksanakan dengan sangat baik. Hal tersebut terbukti bahwa dari hasil tanggapan responden pelaksanaan audit internal mendapatkan skor 1.297. Berdasarkan tabel klasifikasi interval pelaksanaan audit internal bahwa penilaian terhadap skor tersebut adalah sangat baik; (2) Pelaporan keuangan Rumah Sakit Umum Daerah (RSUD) Kota Banjar mendapat penilaian yang sangat baik dari responden, artinya pelaporan keuangan di RSUD Kota Banjar telah dilaksanakan dengan sangat baik. Hal tersebut terbukti bahwa dari hasil tanggapan responden mengenai kualitas pelaporan keuangan mendapatkan skor 709 . Berdasarkan tabel klasifikasi interval kualitas pelaporan keuangan bahwa penilaian terhadap skor tersebut adalah sangat baik; (3) Audit internal berpengaruh positif dan signifikan terhadap kualitas pelaporan keuangan pada Rumah Sakit Umum Daerah (RSUD) Kota Banjar. Hal tersebut menunjukan bahwa jika pelaksanaan audit internal ditingkatkan, maka kualitas pelaporan keuangan yang dihasilkan akan lebih maksimal.

Simpulan penelitian menggambarkan inti dari rumusan masalah, hipotesis, dan hasil penelitian untuk mendukung hipotesis penelitian sebagai solusi dari masalah. Berdasarkan simpulan hasil penelitian tujuan utama dari penelitian ini adalah dapat mengetahui bagaimana audit internal, mengetahui bagaimana kualitas pelaporan keuangan pada RSUD Kota Banjar dan menguji pengaruh audit internal terhadap kualitas pelaporan keuangan.

Dari penelitian yang telah dilakukan dan hasil-hasil yang diperoleh, ada beberapa saran yang dapat diberikan untuk penelitian selanjutnya, yaitu: (1) Implikasi secara teoritis terkait dengan data variabel penelitian, maka agenda penelitian ke depan yaitu perlunya mencoba untuk meneliti variabel-variabel lain yang merupakan faktor-faktor lain yang dapat 
mempengaruhi kualitas pelaporan keuangan; (2) Implikasi secara teoritis dari topik penelitian yang serupa, maka diharapkan pada penelitian ke depan dapat menggunakan data sampel dari beberapa jenis organisasi yang berbeda sehingga dapat memberikan hasil yang bervariasi karena adanya perbedaan karakter dari sampel yang diteliti.

Bagi Rumah Sakit Umum Daerah (RSUD) Kota Banjar dalam pelaksanaan audit internal, auditor sebaiknya tidak memberitahukan kepada objek yang diteliti bahwa akan diadakan pemeriksaan. Hal ini dilakukan agar didapat suatu kondisi yang menggambarkan keadaan yang sebenarnya. Sehingga dengan demikian dapat diketahui penyimpangan-penyimpangan yang terjadi dalam perusahaan. Dari hasil penelitian didapat poin-poin tertentu yang menggambarkan kurang maksimalnya pelaksanaan audit internal dan kualitas pelaporan keuangan, yang diantaranya adalah sebagai berikut: (1) Pelaksanaan audit internal pada tahap pengujian masih perlu dilakukan penggalian informasi yang kompeten dan relevan, sehingga temuan-temuan audit pada kertas kerja auditor internal dapat dijadikan dasar untuk memperbaiki rekomendasi; (2) Informasi yang dihasilkan dari pelaporan keuangan belum memenuhi kriteria andal, karena pelaporan keuangan tidak dapat dipahami oleh semua pihak. Oleh karena itu Pelaporan Keuangan harus disertai dengan Catatan atas Laporan Keuangan (CaLK), sehingga semua pihak yang menggunakan pelaporan keuangan akan mudah untuk memahami, karena pada dasarnya tidak semua pengguna laporan keuangan mempunyai dasar pemahaman akuntansi.

\section{DAFTAR PUSTAKA}

Amalia. 2014. Pengaruh Waktu Penyimpanan terhadap Aktivitas Antibakteri. Ekstrak Kental Daun Sirih (Piper betle), Skripsi, Farmasi Universitas. Gadjah Mada, Yogyakarta.

Bastian, I. 2010. Akuntansi Sektor Publik: Suatu Pengantar. Jakarta: Erlangga.

Susanto, D. 2007. Peranan Audit Internal Terhadap Kepatuhan Manajemen Perusahaan. Skripsi. Bandung: Fakultas Ekonomi Universitas Widyatama.

Sundayani, L. 2013. Pengaruh Audit Internal Terhadap Penerapan Good Corporate Governance $(G C G)$. Skripsi. Bandung:
Fakultas Ekonomi Universitas

Padjadjaran.

Widyaningsih, A. 2010. Pengaruh Audit Internal Terhadap Efektifitas Pengendalian Intern Biaya Produksi. Bandung: Fakultas Ekonomi Universitas Pendidikan Indonesia. 